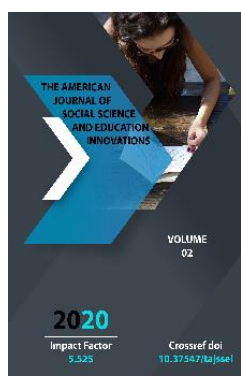

Copyright: Original content from this work may be used under the terms of the creative commons attributes 4.0 licence.

\section{Digitalization Of The Education System In Uzbekistan}

\author{
Gulbakhor Abdullakhanova \\ Associated Professor, Candidate Of Philosophical Sciences, Tashkent State University Of \\ Economics, Tashkent, Uzbekistan \\ Nargis Alimatova \\ Associated Professor, Candidate Of Philosophical Sciences, Tashkent State University Of \\ Economics, Tashkent, Uzbekistan
}

\title{
ABSTRACT
}

This article is devoted to the issue of digitalization of the education system at the present stage of the development of society. In particular, it is noted that digitalization is aimed at training specialists who are guaranteed to be in demand in the labor market, easily and fluently own mobile and Internet technologies. In the age of informatization and digitalization, the teacher himself must change. He should develop new methods and forms of teaching. Attention is drawn to the advantages of the digitalization of education and some of its disadvantages.

\section{KEYWORDS}

Digitalization, education, informatization, information technology, digital technologies.

\section{INTRODUCTION}

The modern period of the development of society is a period when there is a widespread introduction of modern information and communication technologies in all sectors and spheres, first of all, in public administration, healthcare, agriculture, and education.

Complex measures are being implemented in the republic to actively develop the digital 
economy, the transition to which is a requirement of the time.

To accelerate the development of the digital industry in Uzbekistan, increase the competitiveness of the national economy, as well as ensure the implementation of the tasks identified in the State Program for the implementation of the Action Strategy in five priority areas of development of the Republic of Uzbekistan in 2017-2021 in the "Year of Science, Education and Digital Economy Development", The Strategy "Digital Uzbekistan - 2030"was approved.

The importance of further digitalization of the economy of Uzbekistan was noted in the January 2020 Address of the President of the Republic of Uzbekistan Sh.Mirziyoyev to the Oliy Majlis. The head of our state outlined the active transition to the digital economy as one of the top priorities for the next five years: "For sustainable development, we must deeply master digital knowledge and information technology, which will enable us to take the shortest path to achieve comprehensive progress. In today's world, digital technologies play a decisive role in all areas. .... Modern information technologies must be introduced at all stages of the education system." [1]

Uzbekistan has set itself the goal of joining a number of developed states, and for this, it is necessary to carry out accelerated reforms based on science, education, and innovation. And first of all, for this, deep attention should be paid to the education of personnel of the new formation, who are initiators of reforms, who have a strategic vision, deep knowledge, and high qualifications. In this regard, the republic began the process of reforming all levels of education - from preschool to higher education.
The modern education system is able to provide society with a confident transition to the digital era, the benchmark for which is productivity growth, new types of work, and human needs. The ongoing informatization of education creates the basis for a transition to a new level, and digitalization is aimed at training specialists who are guaranteed to be in demand in the labor market, easily and fluently own mobile and Internet technologies, and are also focused on lifelong learning (advanced training) using e-learning.

What is digitalization? This is the widespread introduction of digital technologies in different spheres of life: industry, economy, education, culture, service, etc. Digitalization in education is a transition to an electronic learning system. [2]

Today, a modern person exists in the world of digital technologies, which provide him with great opportunities and prospects, among which one can single out such as learning at any convenient time, continuous education, the ability to design his own educational routes, from consumers of electronic resources to become its creators.

In the age of informatization and digitalization, the teacher himself must change. He should develop new methods and forms of teaching. Now he must be both a bearer of knowledge and a guide through the digital world, i.e. he himself, first of all, must have a comprehensive knowledge of computer literacy, digital technologies. A modern teacher must constantly work to improve not only his general human culture but also constantly work to form an information culture in him.

The digitalization of education allows students to choose the pace of mastering curriculum, teacher, forms, and methods of teaching. 
Important aspects of digitalization of education are the development, widespread introduction, and use of the Internet and mobile communications, both by the teachers themselves and by the students. So, for example, knowledge and ability to work with the Internet and mobile technologies allow a teacher to conduct a lesson and a student to study anywhere and at any time.

The benefits of the digitalization of education are clearly visible in a pandemic when the entire population of the world is forced to stay at home most of the time, but at the same time, it is possible to continue working and studying thanks to the Internet and telecommunications. In these conditions, open online resources have been created and are used, ranging from individual independent assignments, tests to full-scale courses.

However, there are some disadvantages of online education - its focus on meeting shortterm or, at best, medium-term goals. A specialist who has mastered a limited set of knowledge and does not have fundamental basic training can only rely on intellectual "superstructures", the stability of which is illusory. To a certain extent, this is facilitated by the abundance and availability of information, the ability to quickly search for it at the user's request. In addition, the redundancy of information often leads to its superficial perception, significantly increasing the susceptibility of learners who use the Internet, destructive attitudes, and the risks of manipulating consciousness.

In our opinion, the digitalization of education should not mean a complete rejection of the classical form of education. Today we need to look for an optimal balance between them.
Modern education should teach students to apply their knowledge in real life. To do this, one needs to develop functional literacy, learn to analyze text, work with different kinds and directions of information, use one's knowledge to solve applied problems.

Here digitalization has advantages: high visibility and interactive tools. On the one hand, it is possible to realistically recreate situations from life in which a student applies his knowledge, on the other hand, it is easier to model complex metasubject concepts.

Today the role of the teacher is being transformed: new ones are being added to the competencies that have been inherent in this profession for centuries. The availability and quantity of information are constantly growing, and it is very important to be able to work with it. Besides, the development of "flexible" skills is gaining relevance.

An important factor affecting the speed of digitalization of all spheres of human life is the availability of the Internet, information, and communication technologies for people. As the President of Uzbekistan Sh.Mirziyoyev, noted in his message: "Modern information technologies must be introduced at all stages of the education system." And an important point in this should be the fastest completion of the connection to high-speed Internet networks of all cities and regional centers, all villages, and mahallas. [1]

Thus, the essence of digitalization of education is to effectively and flexibly apply the latest technologies to transition to a personalized and result-oriented educational process. 
The American Journal of Social Science and Education Innovations (ISSN - 2689-100x)

Published: December 31, 2020 | Pages: 331-334

Doi: https://doi.org/10.37547/tajssei/Volumeo2Issue12-56

\section{REFERENCES}

1. Mirziyoyev Sh. Message from the

President of the Republic of

Uzbekistan to the Oliy Majlis dated

January 25, 2020/

https://uza.uz/ru/posts/poslanie-

prezidenta-respubliki-uzbekistan-

shavkata-mirziyeev-25-01-2020

2. Digitalization and its place in the

modern world I

https://www.gd.ru/articles/10334-

tsifrovizatsiya 